\title{
Designing and Calibrating Specific Tests for Counter-Attack Skills in Junior Table Tennis Players using Modified Electronic Ball Canon (Table Tennis Robot)
}

Sherif Fathy Saleh*

Table tennis has evolved greatly during the last decade of the twentieth century and the third millennium opens up new horizons for this evolution through investing modern technologies that can be applied to help developing training programs that aim at higher levels of performance to elevate the physical, technical and tactical levels of table tennis players to the world class level. The current research aimed at designing specific tests to measure the ability of counter-attack in table tennis juniors less than (18) years using the Table Tennis Robot and identifying standardized levels and percentiles for these tests. The researcher used the descriptive (survey) approach on a sample of (112) junior table tennis players. Most important findings of this study are the design of theses tests besides deriving their standardized levels and percentiles.

Key words: counter-attack - standardized tests - percentiles.

\section{Introduction:}

$\mathrm{T}$ raining process has been developed greatly in our modern age according to evaluation and assessment approaches, which has a clear effect in this development and a major role in diagnosis, classification, prediction, selection and direction. It is so important that it has become the solid base of planning sports training and one of pillars that carry the training process as a whole. Thomas Kurz \& Mikolaj Zagroski (2007) indicated that evaluation in sports training has an effective role in programs to achieve its desired goals and it is important to identify the strengths and weaknesses of both the player and the program, besides identifying progress, players' training status and their physical, technical, tactical and psychological characteristics. (21) Djokic Zoran (2007) noted that calibrated tests is a very useful means of evaluation in table

*Assistant professor, Sports Training Department, Faculty of Physical Education, Tanta University, Egypt. tennis for both coaches and players as it helps them increasing the efficiency of training, forming a data base for each player and his/her progress and using it in the beginning, middle or end of the season or even in upcoming years. (5)

Laila Farahat (2001) indicated that tests that are designed and calibrated using a sample representing the beneficiaries' community are more useful than those that are designed and calibrated using a sample representing another community, no mater how similar are the two communities. It is one of the most important tools that increase the interest in practice and training to achieve higher performance levels. (9)

Table tennis has evolved greatly during the last decade of the twentieth century and the third millennium opens up new horizons for this evolution through investing modern technologies that can be applied to help developing training programs that aim at higher levels of performance to elevate the physical, 
technical and tactical levels of table tennis players to the world class level.

Attack tactics are now dominant in table tennis and give the opportunity to win the point in the first five balls and increasing the offensive nature of the match. This is in agreement with Sherif Saleh (2002), Wang Dazhong (2005), Baca Arnold (2007), Escobar-Vargas (2007), Hao Zhe (2007), Wang Yali (2007( and Jili Song et al (2009). (17-23-4-8-10-2412)

Kondric Marin et al (2007) indicated that any coach can judge the higher levels players in table tennis through attacks or counter-attacks using loops with different spins to produce the desired speed and spin. The importance of the loop has increased after the modifications made by (ITTF) that increased the ball diameter to $40 \mathrm{~mm}$ and its weight to $2.7 \mathrm{~g}$. This increased the difficulty in dealing with the ball as a result of the decrease of it flight arch. Tepper \& Glenn (2006) noted that this new ball has a speed that reached $180 \mathrm{~km} / \mathrm{h}$ and its spin was more than 150 cycle/second (13-20).

The researcher thinks that due to the changes of flight arch of the new ball, as a result of the decrease of both the size of the ball and its flight arch, the table tennis junior player faces some difficulties in initiating counter-attacks during matches. The modified ball canon (Table Tennis Robot) can specify the spin velocity, volume and type besides the length of the ball flight over the table. The researcher thinks that it is important to make this study to enhance the performance levels of junior table tennis players.

The researcher reviewed several studies that designed tests for attack and loop. These studies include ETTA (1999), Magdy Shawky (2002), Djokic Zoran (2007), Mohamed Abd El-Gawad
(2009) and Manoj Purashwani et al (2009). (6 $8-5-1-14)$

The researcher found that past tests are designed to measure speed and accuracy of attack basic skills only and not the counter-attack skills. These studies used the old ball canon with fixed speed and location and not the modified one that is capable of changing speed with it remote control unit. Also, these studies did not identify spin velocity, volume and type or its flight length over the table for less than (18) years junior players.

According to the researcher's expertise as a coach and head of coaches committee and secretary of the scientific committee in Egyptian Table Tennis Association (ETTA), and from watching several national and international championships and identifying the past tests from reviewing the related literature, he found that evaluating counter-attack skills in table tennis needs to be developed according to the most recent modifications in the game rules and regulations and according to the requirements of speed, spin, altitude and directions. All these requirements necessitate that table tennis players should master counter-attack from all distances and angles of the racquet and table, no matter the distance of the player from the table is. This led the researcher to design tests that measure the ability of counter-attack in junior table tennis players using the modified ball canon that is considered one of the most recent training technologies in table tennis. The device can change directions, speeds and spins of the ball so that its results are more stable and valid than human testers. It also enables us to specify percentiles for tests.

Mohamed Sobhy Hasanain (2003) indicated that standards are values representing the performance of specific community in a specific test. Or, they are tables used to interpret test scores and identify standards that turn row data 
into standardized data to put a level for test scores. Mohamed Hassan Alaawy (2008) noted that there are three major types of standardized scores: self score value, (t) value and percentile. $(11-3)$

\section{Aims:}

1- To design specific tests to measure the ability of counter-attack in table tennis juniors less than (18) years using the modified ball canon.

2- To put standardized levels for the tests measuring the ability of counter-attack in table tennis juniors less than (18) years using the modified ball canon.

3- To put percentiles for the tests measuring the ability of counter-attack in table tennis juniors less than (18) years using the modified ball canon.

\section{Terminology:}

1- Counter-attack (procedural term): it is the ability to attack against the opponent's attack using the same or any other type of spin with one or both faces of the racquet on the table to win a point.

2- Table Tennis Robot: it is a device that enables the player to play without a mate, and with its built-in computer unit it gives the opportunity to train on different speeds, altitudes, spins and directions. This gives the player controlled game-like situations with the ability to remote control the game during performance.(19)

\section{Methodology:}

\section{Approach:}

The researcher used the descriptive (survey) approach.

\section{Sample and Community:}

The research community includes all junior table tennis players less than (18) years registered in the Egyptian Table Tennis Association during the training season 20092010 (127 players).sample was chosen from the players involved in the Open Egyptian National Championship (Mansoura - Egypt) from 22 to 26 August 2009. Sample was chosen purposefully as follows:

- Sample of pilot study (15 players) from the main community and outside the main sample.

- Main sample (112 players).

- The researcher homogenized the sample for growth factors (age, height and weight) and the training period as shown in table (1). 
Table (1)

Sample homogeneity for the research variable $(n=112)$

\begin{tabular}{|c|c|c|c|c|c|c|c|}
\hline S & \multicolumn{2}{|c|}{ Variables } & Measurement & Means & SD & Median & Squewness \\
\hline $1-$ & Growth factors & Age & Year & 17.0375 & 0.5549 & 16.80 & 0.180 \\
\cline { 3 - 8 } & Height & $\mathrm{Cm}$ & 174.312 & 1.857 & 174 & -0.169 \\
\cline { 3 - 8 } & Weight & $\mathrm{Kg}$ & 66.607 & 1.7104 & 66 & 0.336 \\
\hline 2- & \multicolumn{2}{|l|}{ Training period } & Year & 6.1045 & 0.3660 & 5.9 & 0.872 \\
\hline
\end{tabular}

From table (1), it is clear that squewness values ranged from $(0.872)$ to $(-0.169)$ (between $3 \pm)$. This indicates that they are in the moderate curve, indicating the homogeneity of the sample for all variables.

\section{Planning the research experiment:}

Main sample was divided into two groups (56 players each). The first group was divided into two sub-groups (28 players each). This division led to three groups:

- Group (1) $(\mathrm{n}=28)$ to establish the suitability of the recommended tests (easiness and difficulty).

- Group (2) $(n=28)$ to calculate the stability coefficients of the recommended tests.

Table (2)

Sample equivalence for comparing the three groups on all basic variables

\begin{tabular}{|c|c|c|c|c|c|c|c|c|}
\hline $\mathbf{S}$ & \multicolumn{2}{|c|}{ Variables } & Measurement & Groups & Means & SD & Median & Squewness \\
\hline \multirow[t]{9}{*}{$1-$} & \multirow[t]{9}{*}{ Growth factors } & \multirow{3}{*}{ Age } & \multirow{3}{*}{ Year } & $\mathrm{N} 1=28$ & 17.0214 & 0.5640 & 16.800 & 0.229 \\
\hline & & & & $\mathrm{N} 2=28$ & 17.0536 & 0.5494 & 16.950 & 0.129 \\
\hline & & & & $\mathrm{N} 3=56$ & 17.0375 & 0.5630 & 16.800 & 0.192 \\
\hline & & \multirow{3}{*}{ Height } & \multirow{3}{*}{$\mathrm{Cm}$} & $\mathrm{N} 1=28$ & 174.464 & 1.0305 & 175 & 0.210 \\
\hline & & & & $\mathrm{N} 2=28$ & 174.071 & 1.4123 & 174 & -0.390 \\
\hline & & & & $\mathrm{N} 3=56$ & 174.357 & 1.1350 & 174.01 & 0.097 \\
\hline & & \multirow{3}{*}{ Weight } & \multirow{3}{*}{$\mathrm{Kg}$} & $\mathrm{N} 1=28$ & 66.7143 & 1.7397 & 66 & 0.339 \\
\hline & & & & $\mathrm{N} 2=28$ & 66.142 & 1.7995 & 65.500 & 0.674 \\
\hline & & & & $\mathrm{N} 3=56$ & 66.785 & 1.6372 & 66 & 0.255 \\
\hline \multirow[t]{3}{*}{$2-$} & \multirow{3}{*}{\multicolumn{2}{|c|}{ Training period }} & \multirow{3}{*}{ Year } & $\mathrm{N} 1=28$ & 6.092 & 0.3731 & 5.900 & 0.904 \\
\hline & & & & $\mathrm{N} 2=28$ & 6.1179 & 0.3560 & 6 & 0.425 \\
\hline & & & & $\mathrm{N} 3=56$ & 6.1036 & 0.33737 & 5.900 & 0.886 \\
\hline
\end{tabular}

From table (2), it is clear that means are greater than standard deviations and squewness values ranged from (0.904) to (-0.390), indicating that the three groups are homogenized and free from non-moderate distributions. 
To insure that there are no differences between the three groups in the study variables, the researcher performed "One Way ANOVA" as shown in table (3)

Table (3)

One Way ANOVA for comparing the three groups on all basic variables

\begin{tabular}{|c|c|c|c|c|c|c|c|c|}
\hline $\mathbf{S}$ & \multicolumn{2}{|c|}{ Variables } & Measurement & $\begin{array}{c}\text { Variance } \\
\text { source }\end{array}$ & $\begin{array}{c}\text { Squares } \\
\text { sum }\end{array}$ & $\begin{array}{c}\text { Freedom } \\
\text { degrees }\end{array}$ & $\begin{array}{c}\text { Squares } \\
\text { means }\end{array}$ & F Values \\
\hline \multirow[t]{9}{*}{$1-$} & \multirow[t]{9}{*}{ Growth factors } & \multirow{3}{*}{ Age } & \multirow{3}{*}{ Year } & Inter-group & 0.01446 & 2 & 0.00723 & \multirow{3}{*}{0.023} \\
\hline & & & & Intra-groups & 34.168 & 109 & 0.313 & \\
\hline & & & & Total & 34.183 & 111 & & \\
\hline & & \multirow{3}{*}{ Height } & \multirow{3}{*}{$\mathrm{Cm}$} & Inter-group & 2.384 & 2 & 1.192 & \multirow{3}{*}{0.845} \\
\hline & & & & Intra-groups & 153.679 & 109 & 1.410 & \\
\hline & & & & Total & 156.062 & 111 & & \\
\hline & & \multirow{3}{*}{ Weight } & \multirow{3}{*}{$\mathrm{Kg}$} & Inter-group & 8.143 & 2 & 4.071 & \multirow{3}{*}{1.402} \\
\hline & & & & Intra-groups & 3165.57 & 109 & 2.904 & \\
\hline & & & & Total & 324.714 & 111 & & \\
\hline \multirow[t]{3}{*}{$2-$} & \multirow{3}{*}{\multicolumn{2}{|c|}{ Training period }} & \multirow{3}{*}{ Year } & Inter-group & 0.00883 & 2 & 0.00441 & \multirow{3}{*}{0.032} \\
\hline & & & & Intra-groups & 14.859 & 109 & 0.136 & \\
\hline & & & & Total & 14.868 & 111 & & \\
\hline
\end{tabular}

F values on $\mathbf{p} \leq \mathbf{0 . 0 5}=\mathbf{3 . 5 5}$

From table (3), it is clear that there are no statistically significant differences among the three groups on the basic study variables. This means that the existing differences are not significant and the three groups are equivalent.

\section{Procedures of designing tests:}

a) Designing tests:

The researcher designed (8) tests for the counter-attack skill in junior table tennis players using the Table Tennis Robot and he considered the following:

- To give the player the opportunity to perform with one or both faces of the racquet (for hand / back hand).

- The tests should measure different counterattack skills.
- The tests should cover different spots on the table and the player should shoot the balls for all these spots.

- Tests should be game-like situations and movements should be logical and similar to real game situations. Also, the player should be familiar with movements and spin should be increased during the same test.

- Tests should clearly show the player's ability to perform counter-attack.

- Tests should be exciting and motivating for players. To do so, tests of attack alone were indentified through literature review.

- All tests are designed for right-handed players and if the player is left-handed, the 
ball path should be modified and control panel settings should be described.

The preliminary draft of the tests was prepared and taken to experts to give their opinions through the specified form. Experts were (8) professional of the field of table tennis (4 specialized physical education professors and 4 experienced coaches) (appendix 1). Experts gave their opinions and recommendations on the specified form (appendix 2).

\section{b) Indentifying and selecting tests:}

The researcher used the following studies in designing tests: Ertna Patir (2008), Richard MacAfee (2008), Admin Tags (2009), Jili Song et al (2009), Martin Hors (2009), Tamasu Butterfly (2009), USATTF (2009) and Yasser Kamal \& Ahmed Sobhy (2009) (7 - 16-2 - 12 $-15-19-22-25)$

Tests are similar to match situations and are all in game-like form regarding speeds, altitudes, spins and directions. These variables cover all game situations. According to experts' opinions, balls' distances, speeds, spins and hit points with table were modified and tests reached its final form (appendix 3).

\section{c) Trying out tests in its final form:}

The researcher tried out the tests in its final form to identify:

1- Tests after experts modifications.

2- Time used in performing tests.

3- The suitable daily number of tested players.

\section{Administrative and organizational aspects:}

1- The researcher interviewed the team coaches to get their consent on performing tests.
2- The researcher prepared an individual form to record each player's data.

3- The researcher prepared the needed equipments:

- (100) table tennis balls (ITTF approved).

- Table (ITTF approved).

- Net (ITTF approved).

- Table tennis racquet and every player should attend tests with his/her own racquet.

- "Butterfly" ball canon (Amicus 300 Plus)

\section{Pilot study:}

The researcher performed the pilot study on a randomly chosen sample (15 players) form the research community and outside the main sample to make sure that speeds, spins and ball flight distances are suitable.

The researcher developed the tests in its final form and identified each test's time and total time for all tests. He also designed a form for evaluating the counter-attack skills where each player's data are recorded (appendix 5).

\section{Standard procedures for the Table Tennis Robot functioning and assessment procedures:}

1. The device is set in the middle of the table in front of the player and $30 \mathrm{~cm}$ away from the table.

2. The player stands $30 \mathrm{~cm}$ away from the table in front of the device and on the opposite side, holding his/her racquet and ready for performance.

3. The device is set separately for each test according to the following tables: 
Test (1): For hand counter-attack against top-spin loops:

\begin{tabular}{|l|c|c|c|c|}
\hline & Ball A & Ball B & Ball C & Ball DA \\
\hline Ball & 1 & 2 & 3 & 4 \\
\hline Speed & 4 & 14 & 15 & 16 \\
\hline Spin & -2 & 5 & 6 & 6 \\
\hline Long/short & 2 & 6 & 6 & 6 \\
\hline Left/right & 1.5 left & 1.5 left & 1.7 left & 2 left \\
\hline Ball/minute & \multicolumn{5}{|c|}{$50 /$ minute } \\
\hline Type and location & \multicolumn{5}{|c|}{ 120 seconds play } \\
\hline cycle & \multicolumn{5}{|c|}{} \\
\hline
\end{tabular}

Test (2): For hand counter-attack against side-spin loops:

\begin{tabular}{|l|c|c|c|c|}
\hline & Ball A & Ball B & Ball C & Ball DA \\
\hline Ball & 1 & 2 & 3 & 4 \\
\hline Speed & 6 & 12 & 14 & 18 \\
\hline Spin & -1 & 7 & 9 & 9 \\
\hline Long/short & 2 & 6 & 7 & 6 \\
\hline Left/right & 1 left & 1.3 left & 1.5 left & 1.7 left \\
\hline Ball/minute & \multicolumn{5}{|c|}{$50 /$ minute } \\
\hline Type and location & \multicolumn{5}{|c|}{ Programmed } \\
\hline cycle & \multicolumn{5}{|c|}{} \\
\hline
\end{tabular}

Test (3): Back hand counter-attack against top-spin loops:

\begin{tabular}{|l|c|c|c|c|}
\hline & Ball A & Ball B & Ball C & Ball DA \\
\hline Ball & 1 & 2 & 3 & 4 \\
\hline Speed & 5 & 13 & 17 & 15 \\
\hline Spin & -3 & 4 & 5 & 4 \\
\hline Long/short & 2 & 5 & 5 & 5 \\
\hline Left/right & Zero & 3 right & 3.5 right & 4 right \\
\hline Ball/minute & \multicolumn{5}{|c|}{ P0/minute } \\
\hline Type and location & \multicolumn{5}{|c|}{ 120 seconds play } \\
\hline cycle & \multicolumn{5}{|c|}{} \\
\hline
\end{tabular}


Test (4): Back hand counter-attack against side-spin loops:

\begin{tabular}{|l|c|c|c|c|}
\hline & Ball A & Ball B & Ball C & Ball DA \\
\hline Ball & 1 & 2 & 3 & 4 \\
\hline Speed & 3 & 6 & 11 & 9 \\
\hline Spin & -1.5 & -1.5 & -2 & -2 \\
\hline Long/short & 3 & 4 & 5 & 4 \\
\hline Left/right & 2 right & 2 right & 4.5 left & 5 right \\
\hline Ball/minute & \multicolumn{5}{|c|}{ P0/minute } \\
\hline Type and location & \multicolumn{5}{|c|}{120 seconds play } \\
\hline cycle & \multicolumn{5}{|c|}{}
\end{tabular}

Test (5): Smash counter-attack against Smash shots:

\begin{tabular}{|l|c|c|c|c|}
\hline & Ball A & Ball B & Ball C & Ball DA \\
\hline Ball & 1 & 2 & 3 & 4 \\
\hline Speed & 9 & 11 & 13 & 11 \\
\hline Spin & 3 & -1.5 & 3 & 4 \\
\hline Long/short & 5.5 & 5.5 & 5.5 & 6 \\
\hline Left/right & 2.5 left & 2.5 right & 2.5 left & 2.5 right \\
\hline Ball/minute & \multicolumn{5}{|c|}{$50 /$ minute } \\
\hline Type and location & \multicolumn{5}{|c|}{ Programmed seconds play } \\
\hline cycle & \multicolumn{5}{|c|}{} \\
\hline
\end{tabular}

Test (6): Smash counter-attack against loops:

\begin{tabular}{|l|c|c|c|c|}
\hline & Ball A & Ball B & Ball C & Ball DA \\
\hline Ball & 1 & 2 & 3 & 4 \\
\hline Speed & 14 & 14 & 15 & 15 \\
\hline Spin & -1 side & 4 top & -3 side & 9 top \\
\hline Long/short & 4.5 & -4.5 & 4.5 & 4.5 \\
\hline Left/right & 1.5 left & 1.5 right & 2.5 left & 3.5 right \\
\hline Ball/minute & \multicolumn{5}{|c|}{$50 /$ minute } \\
\hline Type and location & \multicolumn{5}{|c|}{120 seconds play } \\
\hline cycle & \multicolumn{5}{|c|}{} \\
\hline
\end{tabular}


Test (7): Random counter-attack (any kind of shots) against any kinds of shots:

\begin{tabular}{|l|c|c|c|c|}
\hline & Ball A & Ball B & Ball C & Ball DA \\
\hline Ball & 1 & 2 & 3 & 4 \\
\hline Speed & 2.5 & 11 & 12 & 17 \\
\hline Spin & -1 & 2 & -3 & 5 \\
\hline Long/short & 2 & 4 & 4 & 6 \\
\hline Left/right & 3 right & 2.5 left & 3.5 right & 3 left \\
\hline Ball/minute & \multicolumn{5}{|c|}{$50 /$ Programmed } \\
\hline Type and location & \multicolumn{5}{|c|}{120 seconds play } \\
\hline cycle & \multicolumn{5}{|c|}{}
\end{tabular}

Test (8): Open (back hand/for hand) counter-attack against back hand/for hand top- and side-spin loops:

\begin{tabular}{|l|c|c|c|c|}
\hline & Ball A & Ball B & Ball C & Ball DA \\
\hline Ball & 1 & 2 & 3 & 4 \\
\hline Speed & 3 & 9 & 12 & 15 \\
\hline Spin & -3 top & -1.5 side & 2 top & 5 side \\
\hline Long/short & 2 & 5 & 4 & 6 \\
\hline Left/right & 2 left & 3.5 right & 3.5 left & 4 right \\
\hline Ball/minute & \multicolumn{5}{|c|}{$50 /$ minute } \\
\hline Type and location & \multicolumn{5}{|c|}{120 seconds play } \\
\hline cycle & \multicolumn{5}{|c|}{} \\
\hline
\end{tabular}

\section{Recording:}

- Coach records the number of balls hit by the player from different locations on the table and balls descending to the middle of the table in front of the player.

- Do not record the balls that get out of the table. (appendix 3)

\section{Statistical treatments:}

The researcher used the following statistics:

- Means. - Standard Deviation.

- Median. - Squewness.
- Pearson's correlation coefficient. Alpha Cronpach $(\alpha)$

- One Way ANOVA Percentiles.

\section{Calibrating the recommended tests:}

1- To insure the easiness/difficulty of the recommended tests, the researcher applied the tests from 4 to 7-7-2009 on the first group $(n=28)$ to insure that tests are suitable for junior players and to identify any problems or difficulties that may happen during the main study. Table (4) showed theses results. 
Means, Standard Deviation, Median and Squewness of first calibration sample scores on recommended tests (n=28)

\begin{tabular}{|c|c|c|c|c|c|}
\hline S & Tests & Means & SD & Median & Squewness \\
\hline $1-$ & For hand counter-attack against top-spin loops & 58.607 & 2.282 & 59 & 0.582 \\
\hline $2-$ & For hand counter-attack against side-spin loops & 54.714 & 2.820 & 55 & -0.207 \\
\hline $3-$ & Back hand counter-attack against for hand-spin loops & 40.892 & 0.875 & 41 & 0.138 \\
\hline 4- & Back hand counter-attack against side-spin loops & 48.071 & 2.814 & 47.50 & 0.372 \\
\hline $5-$ & Smash counter-attack against smash shots & 52.142 & 1.0789 & 52 & 1.221 \\
\hline $6-$ & Smash counter-attack against loops & 39.785 & 1.2869 & 40 & -1.815 \\
\hline 7- & $\begin{array}{l}\text { Random counter-attack (using any attack shots) } \\
\text { against any kind of attack shots }\end{array}$ & 53.785 & 0.686 & 54 & 0.302 \\
\hline $8-$ & $\begin{array}{l}\text { Open (for hand/back hand) counter-attack against for } \\
\text { hand/back hand top-spin and side-spin loops }\end{array}$ & 42.285 & 0.8100 & 42 & 0.312 \\
\hline
\end{tabular}

Table (4) indicates that all means are higher than standard deviation for all tests. This is a clear indication that the performance of all tests is free from non-moderate distributions as squewness values ranged from $(1,221)$ to

2- Validity of tests:

The researcher calculated the validity of the recommended tests from 11 to 14-7-2009 using the following methods:

a) Validity of differences between
contrasted groups. (-1.815)

b) Internal consistency of each test.

To identify the ability of tests to differentiate between high and low levels, tests were applied on the third group $(n=56)$. Scores were sorted in a descending order for each test. Upper quartile and lower quartile (14 players for each quartile) were identified as follows: 
Table (5)

Validity of differences for the recommended tests $(n=56)$

\begin{tabular}{|c|c|c|c|c|c|c|}
\hline \multirow{2}{*}{$\mathrm{S}$} & \multirow{2}{*}{ Tests } & \multicolumn{2}{|c|}{$\begin{array}{l}\text { Upper } \quad \text { quartile } \\
(\mathrm{n}=14)\end{array}$} & \multicolumn{2}{|c|}{$\begin{array}{l}\text { Lower quartile } \\
(\mathrm{n}=14)\end{array}$} & \multirow{2}{*}{$\begin{array}{l}\text { (t) } \\
\text { value }\end{array}$} \\
\hline & & Means & SD & Means & SD & \\
\hline $1-$ & For hand counter-attack against top-spin loops & 47.285 & 0.825 & 61.857 & 1.099 & $39.65 *$ \\
\hline $2-$ & For hand counter-attack against side-spin loops & 52.285 & 1.540 & 64.017 & 0.916 & $24.597 *$ \\
\hline $3-$ & Back hand counter-attack against for hand-spin loops & 35.214 & 0.6993 & 40.00 & 1.109 & $13.654 *$ \\
\hline 4- & Back hand counter-attack against side-spin loops & 41.714 & 0.2301 & 51.00 & 1.797 & $11.898 *$ \\
\hline $5-$ & Smash counter-attack against smash shots & 44.857 & 1.231 & 52.142 & 1.099 & $16.513 *$ \\
\hline $6-$ & Smash counter-attack against loops & 35.214 & 0.6993 & 39.785 & 1.311 & $11.509 *$ \\
\hline $7-$ & $\begin{array}{l}\text { Random counter-attack (using any attack shots) } \\
\text { against any kind of attack shots }\end{array}$ & 43.500 & 0.3391 & 53.69 & 0.699 & $11.115^{*}$ \\
\hline $8-$ & $\begin{array}{l}\text { Open (for hand/back hand) counter-attack against for } \\
\text { hand/back hand top-spin and side-spin loops }\end{array}$ & 30.928 & 0.8287 & 42.285 & 0.825 & $36.330^{*}$ \\
\hline
\end{tabular}

(t) Table values on $\mathbf{p} \leq \mathbf{0 . 0 5}=\mathbf{2 . 1 4}$

Table (5) shows statistically significant differences $(p \leq 0.05)$ between the upper group and the lower group on scores of the recommended tests. This indicates that these tests are valid and capable of differentiating between the two different groups of junior table tennis players.

3- Stability of tests:

The researcher identified the stability of the recommended tests from 28 to 31-7-2009 using the following:

a) Test/re-test procedures. b) ( $\alpha$ ) Cronbach coefficient.

The second group ( $\mathrm{n}=28)$ was tested using the recommended tests and then re-tested using the same tests after (10) days to calculate correlation coefficient (r) and $(\alpha)$ Cronbach coefficient as shown in table (6). 
Table (5)

Stability of the recommended tests $(n=56)$

\begin{tabular}{|c|c|c|c|c|c|c|c|}
\hline \multirow{2}{*}{$\mathrm{S}$} & \multirow{2}{*}{ Tests } & \multicolumn{2}{|c|}{ Tests } & \multicolumn{2}{|c|}{ Re-test } & \multirow{2}{*}{$(\mathrm{r})$} & \multirow{2}{*}{$(\alpha)$} \\
\hline & & Means & SD & Means & SD & & \\
\hline $1-$ & For hand counter-attack against top-spin loops & 61.857 & 1.099 & 62.214 & 1.050 & $0.894 *$ & 0.944 \\
\hline $2-$ & For hand counter-attack against side-spin loops & 64.017 & 0.916 & 64.278 & 1.193 & $0.757^{*}$ & 0.854 \\
\hline $3-$ & $\begin{array}{l}\text { Back hand counter-attack against for hand-spin } \\
\text { loops }\end{array}$ & 40.00 & 1.109 & 40.464 & 1.046 & $0.895^{*}$ & 0.9444 \\
\hline 4- & Back hand counter-attack against side-spin loops & 51.00 & 1.797 & 51.071 & 2.164 & $0.909 *$ & 0.952 \\
\hline $5-$ & Smash counter-attack against smash shots & 52.142 & 1.099 & 52.500 & 0.940 & $0.669^{*}$ & 0.802 \\
\hline 6- & Smash counter-attack against loops & 39.785 & 1.3114 & 39.928 & 1.730 & $0.806^{*}$ & 0.892 \\
\hline $7-$ & $\begin{array}{l}\text { Random counter-attack (using any attack shots) } \\
\text { against any kind of attack shots }\end{array}$ & 53.785 & 0.6993 & 54.00 & 0.784 & $0.841^{*}$ & 0.913 \\
\hline $8-$ & $\begin{array}{l}\text { Open (for hand/back hand) counter-attack against } \\
\text { for hand/back hand top-spin and side-spin loops }\end{array}$ & 42.285 & 0.8254 & 42.571 & 0.755 & $0.828 *$ & 0.905 \\
\hline
\end{tabular}

(r) Values on $\mathbf{p} \leq \mathbf{0 . 0 5}=\mathbf{0 . 7 0 7}$

From table (6), stability coefficients for the counter-attack skills tests were significant on $\mathbf{p} \leq \mathbf{0 . 0 5}$ between test and re-test. When applying $(\alpha)$ Cronbach coefficient on the tests, as they are considered as units of the whole counterattacks skills test, $(\alpha)$ value was 0.9974 .

\section{Deriving Standards:}

After insuring the validity and stability of the recommended tests, they were applied to the whole research sample $(n=112)$ from 22 to $26-8$ 2009 during the Open Egyptian National Championship (Mansoura - Egypt) to prepare tables of standardized levels and percentiles of the sample row points. Percentiles are one of most popular methods of evaluation and data presentation as they are more significant and accurate in distribution and help classifying individuals into graded levels (11) as shown in the following tables. 
Table (7)

Standardized levels of counter-attack tests for junior table tennis players using the Table Tennis Robot (n=112)

\begin{tabular}{|c|c|c|c|c|c|c|c|}
\hline \multicolumn{2}{|c|}{$\begin{array}{l}\text { (1) For hand counter- } \\
\text { attack against top-spin } \\
\text { loops }\end{array}$} & \multicolumn{2}{|c|}{$\begin{array}{l}\text { (2) For hand counter- } \\
\text { attack against side-spin } \\
\text { loops }\end{array}$} & \multicolumn{2}{|c|}{$\begin{array}{l}\text { (3) Back hand counter- } \\
\text { attack against for hand- } \\
\text { spin loops }\end{array}$} & \multicolumn{2}{|c|}{$\begin{array}{l}\text { (4) Back hand counter- } \\
\text { attack against side-spin } \\
\text { loops }\end{array}$} \\
\hline $\begin{array}{l}\text { Row } \\
\text { points }\end{array}$ & $\begin{array}{c}\text { Standardized } \\
\text { points }\end{array}$ & $\begin{array}{l}\text { Row } \\
\text { points }\end{array}$ & $\begin{array}{c}\text { Standardized } \\
\text { points }\end{array}$ & $\begin{array}{c}\text { Row } \\
\text { points }\end{array}$ & $\begin{array}{l}\text { Standardized } \\
\text { points }\end{array}$ & $\begin{array}{c}\text { Row } \\
\text { points }\end{array}$ & $\begin{array}{c}\text { Standardized } \\
\text { points }\end{array}$ \\
\hline ro & 1.01. & $\leq 7$ & $1 . \leqslant \leqslant V_{-}$ & $r T$ & $1.7 r \leq$ & $r$. & $1.7 \leqslant 1$. \\
\hline "ᄉ & $1 . Y V V=$ & $\varepsilon \wedge$ & 1.491. & $r q$ & $1 . r \leqslant 0_{-}$ & rr & $1.1 \leqslant \cdot-$ \\
\hline$\leqslant 1$ & $1 . \pm \leq \varepsilon-$ & 0. & 1.150 & r & 1.109 & سז & $1 . r 10_{-}$ \\
\hline$\leqslant 0$ & $\cdot V r \varepsilon_{-}$ & 01 & $1.0 V_{-}$ & rT & 1.97 & דו & 1.119. \\
\hline$\varepsilon \wedge$ & $\because 0 . Y_{-}$ & or & $\because 9 \vee 9$ & $r \varepsilon$ & $\cdot \wedge \wedge \Lambda_{-}$ & rq & $\cdot A V Y_{-}$ \\
\hline$\leqslant 9$ & $\because$ หั9. & $0 \leqslant$ & .AYYA_ & ro & $\because$ VAV_ & $\varepsilon$. & $\because \vee \wedge \Lambda_{-}$ \\
\hline or & $.11 \leq$ & 00 & $\because V \leq \leqslant V_{-}$ & r & $.79 \leq$ & $\leqslant r$ &. OrT_ \\
\hline 00 & $\because \varepsilon \cdot \wedge$ & 09 & $.01 \cdot-$ & rv & $.7 \cdot 9-$ & $\leqslant 0$ & .OrT_ \\
\hline ov & .1909 & 09 & $\because \leqslant r_{-}$ & rq & $\because \leqslant 10_{-}$ & $\leqslant V$ & $.191-$ \\
\hline 09 &. & Tr & $\because 9 \Lambda_{-}$ & $\varepsilon$. & . MTY & $\leqslant \wedge$ & $\cdot 1 \cdot 7_{-}$ \\
\hline 71 & .0 .71 & זו & $.119_{-}$ & $\leqslant \varepsilon$ & $\because \leqslant \wedge q_{-}$ & 0 . & זד. \\
\hline זי & $.77 ו r$ & $7 V$ &. .194 & $\leqslant 0$ & $\cdot 1 \leqslant 1-$ & or & . MTE \\
\hline 77 & . А१५ & 79 & $\cdot r \leqslant \Lambda$ & $\leqslant 7$ & . & $0 \leqslant$ &.$\leqslant .0$ \\
\hline 71 & $1 . \leqslant 9$ & VI & $.0 . \varepsilon$ & $\leqslant \curlywedge$ & $\cdot \leqslant r \cdot q_{-}$ & 07 & $.0 \times 0$ \\
\hline 79 & $1.1 \times 7$ & $V T$ & $\cdot .771$ & 01 & $\cdot .799$ & $0 \wedge$ & $\because V \leq 7$ \\
\hline$V T$ & $1 . \leqslant r$ & $V 7$ & .190 & or & $\because \wedge 10$ & 71 & $1 \ldots 1$ \\
\hline vo & 1.091 & $\vee \wedge$ & 1.01 & 00 & $1 . \times 1$ & $7 \leq$ & $1 . r O V$ \\
\hline$V 7$ & 1.779 & 19 & $1.1 \times 9$ & 07 & $1.17 \varepsilon$ & 77 & $1 . \leqslant Y \wedge$ \\
\hline$\vee \wedge$ & I. $\wedge Y \varepsilon$ & $\wedge \wedge$ & I.ATr & 09 & $1 . \varepsilon \leqslant r$ & 71 & 1.091 \\
\hline$\wedge$. & $1.9 \vee 9$ & 9. & 1.911 & 7. & 1.047 & $v$. & 1.879 \\
\hline
\end{tabular}

Table (7) (cont...)

\begin{tabular}{|c|c|c|c|c|c|c|c|}
\hline \multicolumn{2}{|c|}{$\begin{array}{l}\text { (5) Smash counter-attack } \\
\text { against smash shots }\end{array}$} & \multicolumn{2}{|c|}{$\begin{array}{c}\text { (6) Smash counter-attack } \\
\text { against loops }\end{array}$} & \multicolumn{2}{|c|}{$\begin{array}{c}\text { (7) Random counter- } \\
\text { attack (using any attack } \\
\text { shots) against any kind of } \\
\text { attack shots }\end{array}$} & \multicolumn{2}{|c|}{$\begin{array}{l}\text { (8) Open (for hand/back } \\
\text { hand) counter-attack } \\
\text { against for hand/back } \\
\text { hand top-spin and side- } \\
\text { spin loops }\end{array}$} \\
\hline $\begin{array}{l}\text { Row } \\
\text { points }\end{array}$ & $\begin{array}{l}\text { Standardized } \\
\text { points }\end{array}$ & $\begin{array}{l}\text { Row } \\
\text { points }\end{array}$ & $\begin{array}{l}\text { Standardized } \\
\text { points }\end{array}$ & $\begin{array}{l}\text { Row } \\
\text { points }\end{array}$ & $\begin{array}{l}\text { Standardized } \\
\text { points }\end{array}$ & $\begin{array}{l}\text { Row } \\
\text { points }\end{array}$ & $\begin{array}{c}\text { Standardized } \\
\text { points }\end{array}$ \\
\hline ro & $1.7 \leq 1-$ & ro & $1.7 \leqslant 1-$ & rv & $1.041-$ & rV & $1.0 \cdot V_{-}$ \\
\hline rv & $1 . \Sigma T Y_{-}$ & TV & $1 . \Sigma 7 \pi-$ & rq & $1 . r 09$ & rq & $1 . r \wedge V_{-}$ \\
\hline rq & $1 . Y \wedge \varepsilon_{-}$ & rq & 1. r人ז_ & $\varepsilon$. & 1.YVT- & Tr & $1.1 \leqslant V_{-}$ \\
\hline § & $1.190_{-}$ & $r$. & $1.19 V_{-}$ & $\varepsilon r$ & $1.1 \cdot 1 V_{-}$ & rv & $\cdot 9 \cdot 7$ \\
\hline$\leq 0$ & $\because \vee 0 .-$ & ri & $1.1 \cdot \Lambda_{-}$ & $\varepsilon r$ & $1.1 \cdot 10_{-}$ & $\varepsilon \cdot$ & $\because$ VYT- \\
\hline$\leqslant \wedge$ & • rᄉr. & rT & 1.919. & $\varepsilon \varepsilon$ & .949 & $\varepsilon r$ & $\because 0 \leqslant 0_{-}$ \\
\hline 01 & $\cdot r \mid I_{-}$ & Tะ & $\cdot . \wedge \leq 1-$ & $\leqslant 7$ & $\therefore$ VOVV_ & $\leq 0$ & $\cdot \leqslant Y O_{-}$ \\
\hline
\end{tabular}




\begin{tabular}{|c|c|c|c|c|c|c|c|}
\hline \multicolumn{2}{|c|}{$\begin{array}{l}\text { (5) Smash counter-attack } \\
\text { against smash shots }\end{array}$} & \multicolumn{2}{|c|}{$\begin{array}{c}\text { (6) Smash counter-attack } \\
\text { against loops }\end{array}$} & \multicolumn{2}{|c|}{$\begin{array}{c}\text { (7) Random counter- } \\
\text { attack (using any attack } \\
\text { shots) against any kind of } \\
\text { attack shots }\end{array}$} & \multicolumn{2}{|c|}{$\begin{array}{l}\text { (8) Open (for hand/back } \\
\text { hand) counter-attack } \\
\text { against for hand/back } \\
\text { hand top-spin and side- } \\
\text { spin loops }\end{array}$} \\
\hline or & $.1 T V_{-}$ & דr & • & $\varepsilon V$ & $.7 \times 1-$ & $\leqslant 9$ & $.1 \wedge 0_{-}$ \\
\hline or & $\because+r \Lambda I-$ & rᄉ & $\because \leqslant 10_{-}$ & $\leqslant \wedge$ & $.010_{-}$ & $0 \leqslant$ & $.110 \leqslant$ \\
\hline 00 & .119 & « & $\cdot r \mid \wedge \varepsilon$ & or & .100 & 09 &.$\{17$ \\
\hline ov & • Mוג. & $\varepsilon r$ & $\because \leqslant .0$ & 00 & $\because .171$ & TT & .079 \\
\hline 09 & $\cdot . \leqslant 97$ & $\leqslant 0$ &. $.1 T V$ & ov & $.1 \wedge \wedge$ & 70 &.$\vee \vee \vee T$ \\
\hline 71 & $.7 \vee \leq$ & $\leqslant V$ & .10 & 09 & . זח. & 71 & $.90 \mathrm{~V}$ \\
\hline אד & $\cdot$. AOr & $\leqslant 9$ &.$\leqslant q \pi$ & Tr & .711 & $\vee$. & $1 . V V$ \\
\hline 77 & 1.119 & 01 & $.7 \times 1$ & זד & $\cdot V \cdot \varepsilon$ & VY & $1.19 V$ \\
\hline 71 & $1 . Y 9 V$ & or & $\cdot \wedge \leq q$ & 70 & $\because \wedge \vee 0$ & $V \varepsilon$ & $1 . r 1 V$ \\
\hline 79 & $1 . r \wedge t$ & 07 & 1.117 & 71 & אזו. & VV & $1 . \leqslant 9 V$ \\
\hline$v \cdot$ & $1 . \leqslant \vee 0$ & $0 \wedge$ & $1 . r 9 r$ & v. & $1 . r .0$ & $\wedge$. & $1.7 \vee \wedge$ \\
\hline$V_{1}$ & $1.70 r$ & 7. & $1 . \leqslant v 1$ & vi & 1.491 & 1) & 1.VR \\
\hline VY & $1.70 r$ & TY & $1.7 \leq 9$ & VY & $1 . \varepsilon V V$ & 10 & $1.9 \times 9$ \\
\hline
\end{tabular}

Table (8)

Percentiles and its corresponding points of counter-attack tests for junior table tennis players using the Table Tennis $\operatorname{Robot}(n=112)$

\begin{tabular}{|c|c|c|c|c|}
\hline Percentiles & $\begin{array}{c}\text { (1) For hand } \\
\text { counter-attack } \\
\text { against top-spin } \\
\text { loops }\end{array}$ & $\begin{array}{c}\text { (2) For hand } \\
\text { counter-attack } \\
\text { against side-spin } \\
\text { loops }\end{array}$ & $\begin{array}{l}\text { (3) Back hand } \\
\text { counter-attack } \\
\text { against for hand- } \\
\text { spin loops }\end{array}$ & $\begin{array}{l}\text { (4) Back hand } \\
\text { counter-attack } \\
\text { against side-spin } \\
\text { loops }\end{array}$ \\
\hline $1 \ldots$ & $\Lambda$. & 9. & 7. & $v \cdot$ \\
\hline 90 & $\vee \wedge$ & $\Lambda \Lambda$ & 09 & 71 \\
\hline 9. & vo & 1o & $0 \wedge$ & 70 \\
\hline 10 & VT & Ar & 07 & $7 \varepsilon$ \\
\hline$\wedge$. & 77 & V7 & 00 & זד \\
\hline vo & זיד & $V T$ & $0 \leq$ & $0 \Lambda$ \\
\hline v. & 71 & V) & or & 07 \\
\hline 70 & 09 & 79 & 01 & 00 \\
\hline 7. & ov & $7 V$ & $\leqslant \wedge$ & $0 \leqslant$ \\
\hline 00 & 00 & 70 & $\leqslant 7$ & or \\
\hline o. & or & זיד & $\varepsilon r$ & $\leqslant 9$ \\
\hline$\leq 0$ & 01 & 71 & $\varepsilon r$ & $\leqslant V$ \\
\hline$\varepsilon$. & $\leqslant 9$ & 09 & rq & $\leqslant 0$ \\
\hline ro & $\leqslant V$ & 01 & $r v$ & $\varepsilon r$ \\
\hline r. & $\leqslant 0$ & 00 & די & $\leqslant 1$ \\
\hline ro & $\leqslant \varepsilon$ & $0 \leqslant$ & $r \varepsilon$ & rq \\
\hline$r$. & $\varepsilon r$ & or & rT & rv \\
\hline
\end{tabular}




\begin{tabular}{|c|c|c|c|c|}
\hline Percentiles & $\begin{array}{c}\text { (1) For hand } \\
\text { counter-attack } \\
\text { against top-spin } \\
\text { loops }\end{array}$ & $\begin{array}{c}\text { (2) For hand } \\
\text { counter-attack } \\
\text { against side-spin } \\
\text { loops }\end{array}$ & $\begin{array}{l}\text { (3) Back hand } \\
\text { counter-attack } \\
\text { against for hand- } \\
\text { spin loops }\end{array}$ & $\begin{array}{c}\text { (4) Back hand } \\
\text { counter-attack } \\
\text { against side-spin } \\
\text { loops }\end{array}$ \\
\hline 10 & $\varepsilon$. & 0. & $r$. & דו \\
\hline 1. & rᄉ & $\varepsilon \wedge$ & $r V$ & rr \\
\hline 0 & ro & $\leq 7$ & $r y$ & $r$. \\
\hline
\end{tabular}

Table (8) (cont...)

\begin{tabular}{|c|c|c|c|c|}
\hline Percentiles & $\begin{array}{c}\text { (5) Smash } \\
\text { counter-attack } \\
\text { against smash } \\
\text { shots }\end{array}$ & $\begin{array}{c}\text { (6) Smash } \\
\text { counter-attack } \\
\text { against loops }\end{array}$ & $\begin{array}{c}\text { (7) Random } \\
\text { counter-attack } \\
\text { (using any attack } \\
\text { shots) against any } \\
\text { kind of attack } \\
\text { shots }\end{array}$ & $\begin{array}{c}\text { (8) Open (for } \\
\text { hand/back hand) } \\
\text { counter-attack } \\
\text { against for } \\
\text { hand/back hand } \\
\text { top-spin and side- } \\
\text { spin loops }\end{array}$ \\
\hline $1 \ldots$ & $V Y$ & $7 r$ & $V Y$ & 10 \\
\hline 90 & VI & 71 & VI & N) \\
\hline 9. & $v$. & 7. & $\vee$. & $V V$ \\
\hline 10 & 71 & 09 & 79 & VT \\
\hline$\Lambda$. & 77 & 07 & 77 & $7 V$ \\
\hline vo & זד & or & $7 \varepsilon$ & $\pi r$ \\
\hline$v$. & 71 & 01 & Tr & 7. \\
\hline 70 & 09 & $\leqslant 9$ & 7. & 09 \\
\hline 7. & ov & $\Sigma V$ & 09 & ov \\
\hline 00 & 00 & $\leq 0$ & ov & $0 \leqslant$ \\
\hline o. & or & $\varepsilon r$ & 00 & or \\
\hline$\leqslant 0$ & 01 & $\leqslant 1$ & or & $\leqslant 9$ \\
\hline$\varepsilon$. & $\leqslant 9$ & rq & 0. & $\leqslant 0$ \\
\hline ro & $\leqslant \wedge$ & rᄉ & $\leqslant 9$ & $\leqslant r$ \\
\hline$r$. & $\leqslant 7$ & די & $\varepsilon \wedge$ & $\varepsilon$ \\
\hline ro & $\leqslant \varepsilon$ & $r \varepsilon$ & $\leqslant 7$ & rᄉ \\
\hline$r$. & $\varepsilon r$ & rr & $\varepsilon \varepsilon$ & $r \leq$ \\
\hline 10 & «1 & ו & $\varepsilon r$ & אי \\
\hline 1. & $r \Lambda$ & rᄉ & $\varepsilon$. & r. \\
\hline 0 & ro & ro & rv & $r V$ \\
\hline
\end{tabular}

Through to percentiles, the player can be researcher thinks that these levels can be as classified according to his/her row points to follows: several levels from poor to excellent. The 
- Very poor (less than 5\% to $25 \%$ )

- Poor (36\% to $45 \%)$

- Fair (46\% to $60 \%)$

- Good (61\% to $79 \%)$

- Excellent (higher than $80 \%$ and above)

As the technical level of the counter-attack skill is identified, the researcher indicates the importance of standardized levels and percentiles in this age group to evaluate the counter-attack skill in junior table tennis players (less than 18 years).

\section{Conclusions:}

The researcher concluded the following:

1- A set of specific tests for counter-attack skills for junior table tennis players using the Table Tennis Robot were designed. These tests are stable and valid and can measure the specific skills.

2- The recommended tests shed light on strengths and weaknesses of junior players' ability to perform counter-attack from different angles and distances.

3- The specifications of the recommended tests (ball speed, spin and distance) can be used for measuring the counter-attack skill using the Table Tennis Robot.

4- The recommended tests help classifying players and developing their abilities according to modern developments in table tennis.

5- The researcher concluded the standardized levels of counter-attack skills tests for junior table tennis players less than 18 years.

6- The researcher concluded the percentiles of counter-attack skills tests for junior table tennis players less than 18 years.

\section{References:}

1- Abd El-Gawad, Mohamed A. (2009): A
7- Levels of table tennis junior players were identified according to other junior players' performance on the same tests.

\section{Recommendations:}

The researcher recommends the following:

1- To use counter-attacks skills tests for junior table tennis players using Table Tennis Robot in the training and selection processes of junior table tennis players.

2- To use counter-attacks skills tests for junior table tennis players using Table Tennis Robot as a means that help evaluating table tennis players and training counter-attack.

3- To use the conclusions of this research as guidelines for preparing and designing training programs for table tennis junior players.

4- The concluded test results represent indicators of technical performance of the sample and it is necessary to use them in evaluating and monitoring performance curves through follow-up assessments on suitable time intervals.

5- Performing further studies for designing sets of specific tests for measuring the defense abilities of table tennis players using the modified using Table Tennis Robot.

6- Researchers should study other aspects of the modified Table Tennis Robot as it is related to technical and tactical preparations, the most important requirements needed to reach higher levels.

recommended training program using ball canon to develop s effect on counter-attack skill in junior table tennis players. Master 
thesis, Faculty of Physical Education, Tanta University (In Arabic)

r. Admin tags (2009): Close to the Table Long Pips Attack and Defense Techniques, http://www.tabletennisball.net/table tennis/, Mar, 2009.

3- Allawy, Mohamed H. \& Radwan, Mohamed N. (2008): Assessment in Physical Education and Sports Psychology. Dar Al-Fikr Al-Araby, Cairo, Egypt (In Arabic)

¿- Baca Arnold (2007): Qualitative game analysis in table Tennis,

10th Anniversary ITTF Sports Science Congress, University of Zagreb, Croatia, May, 2007.

5- Djoki_Zoran (2007): Testing perfection and monitoring of motor abilities of table tennis players, 10th Anniversary ITTF Sports Science Congress, University of Zagreb, Croatia, May ,2007 .

6- English table tennis association (ETTA) (1999): Sisa protocols-table tennis Pretoria: sports scientific and information Agency, 1999.

V- Ertna patir (2008): Drills for Table Tennis http://www.newgy.com/Products/Benefits. html , 2008.

8- Escobar-Vargas Jorge (2007): Notational analysis for competition in table Tennis (part I): based Format analysis, 10th Anniversary ITTF Sports Science Congress, University of Zagreb, Croatia, and May, 2007.

9- Farahat, Laia A. (2007): Assessment and Testing in Physical Education. $4^{\text {th }}$ ED Markaz Al-Ketab Press, Cairo, Egypt (In Arabic)

- Hao, Zhe (2007): Analysis on technic and

1. tactics of Ryu Seung-Min in man's singles table tennis final and semifinal of the 28th Olympic games in Athens , 10th Anniversary ITTF Sports Science Congress , University of Zagreb, Croatia, May ,2007
11 Hasanain, Mohamed H. (2003): Assessment and Evaluation in Physical Education - Part 1, $5^{\text {th }}$ ED. Dar Al-Fikr AlAraby, Cairo, Egypt (In Arabic)

- Jili Song, Zhe Hao, Zhensheng Tian,

ir Yujiao Hao (2009): Analysis on Technique and Tactics of Lin $\mathrm{Ma}$ and Hao Wang in the Men's Single Table Tennis Final in the 29th Olympic Games ,11 th ITTF sports Science Congress in Japan , http://www.jtta.or.jp/11th_ittf_ssc ,April 2009 .

13 Kondric, Miran SUPEJ, Matej, NEMEC, Bojan, HUDETZ, Radivoj, KOSCAK, Jure (2007): Possibilities to reduce speed and spin by changing the thickness of sponge, upper layer or total thickness of sandwich Rubber, 10th Anniversary ITTF Sports Science Congress, University of Zagreb, Croatia, May, 2007.

14 Manoj Purashwani ,Pushpendra Purashwani 1 . A. K. Datta (2009): Construction of Norms for Skill Test Table Tennis Players, 11 the ITTF sports Science Congress in Japan, http://www.jtta.or.jp/11th_ittf_ssc,April 2009.

15 Martin hors (2009): Table Tennis Skill Level Tests, http://www.allabouttabletennis.com/tabletennis-skill.html,2009 .

16 Richard MacAfee (2008): Simple Drills for - Table Tennis / Ping-Pong

http://tabletennis.about.com/od/drillsroutine s/ig/Simple-Drills-in-Ping-Pong, 2008

17 Saleh, Sherif F. (2002): Analytical study for the individual tactical performance of higher level table tennis players in the light of the international codes and regulations 2001. The scientific Journal of Physical Education and Sports. Faculty of Physical Education for Women, Alexandria University Vol23, July 2002 (In Arabic). 
18 Shawky, Magdy A. (2002): Table Tennis:

- Theoretical and Practical Frameworks. AlMarkaz Al-Araby Press, Cairo, Egypt (In Arabic).

19 Tamasu Butterfly (2009): Amicus 3000

- Plus table tennis robot, www.butterflyworld.com , 2009.

20 Tepper \&Glenn (2006): Table Tennis ITTF

- Level 1 Coaching Manual, printed by shanghi Mimsun Packaging \&Printing Company, Oct, 2006.

21 Thomas Kurz and Mikolaj Zagorski

- (2007): Science of Sports Training: How to Plan and Control Training for Peak Performance, 3 nd edition, Stadion Publishing Co, USA,2007 .

22 USA, table tennis Federation (2009):

- Drills Library ,www.usatt.org/organization/instructors_gu ide.pdf, 2009

23 Wang Dazhong (2005): An Analysis of the

- 11-point System of the Table Tennis from Communication Point of View, 9 th ITTF sports Science Congress in Shanghai, Jiao tong University, No 69, China, April, 2005.

24 Wang Yali (2007): On the analysis of

- backhand attacking tactics of world famous male shake hands grip players, 10th Anniversary ITTF Sports Science Congress, University of Zagreb, Croatia, May, 2007.

25 Yasser Kamal Ghoniem, Ahmed Soubhy

- Salem (2009): Analytical study for Some Offensive Skills for Advanced Level Junior Players in ITTF Pro-Tour Egypt 2008, 11 th ITTF sports Science Congress in Japan, http://www.jtta.or.jp/11th_ittf_ssc/, April 2009. 